\title{
Kewenangan Notaris dalam Pembuatan Akta Pernyataan Keputusan Rapat Umum Pemegang Saham Perseroan Terbatas di Kabupaten Badung
}

\author{
Ida Ayu Karina Diantari ${ }^{1}$
}

1Program Studi Magister (S2) kenotariatan Fakultas Hukum Universitas Udayana, BaliIndonesia, E-mail: karinadiantari93@gmail.com

\begin{tabular}{l}
\hline Info Artikel \\
\hline Keywords : \\
Authority notary, statement \\
certificate of meeting \\
decision,Badung \\
\\
Corresponding Author: \\
Ida Ayu Karina Diantari, \\
E-mail: \\
karinadiantari93@gmail.com \\
Ko.24843/ AC.2018.v03.i03.p0 \\
Kewenangan notaris, Akta \\
Pernyataan Keputusan Rapat, \\
Badung
\end{tabular}

\begin{abstract}
General Meeting of Shareholders (GMS), in principle, is made in the form of an original deed carried out in front of a notary or included in the meeting minutes in the form of a deed under the hand wherein the deed is converted into an authentic deed. This study uses empirical research methods by conducting interviews with Notaries based on their experience in making the statement deed, so the formulation of the problem made to limit and make more focus in conducting research is about the notary's responsibility in making deeds related to the general meeting of shareholders, as well as reviewing aspects of protection obtained by a notary public regarding the deed. The conclusion obtained from the research is that according to Article 15 of Act Number 2 of 2014 concerning Notary Position, a Notary has the authority to make Deed of Decision of Limited General Meeting of Shareholders and will be an authentic deed if made in the form of a notarial deed called Decree of Decision General Meeting of Shareholders.
\end{abstract}

\begin{tabular}{l} 
Abstrak \\
\hline Rapat Umum Pemegang Saham (RUPS), pada pokoknua dibuat \\
dalam bentuk akta asli yang dibuat didepan seorang notaris atau \\
disertakan pada notulensi rapat berupa akta dibawah tangan \\
dimana selanjutnya akta tersebut diubah menjadi akta otentik. \\
Penelitian ini menggunakan metode penelitian empiris dengan \\
cara melakukan wawancara kepada Notaris berdasarkan \\
pengalamannya dalam membuat akta pernyataan tersebut \\
dengan demikian rumusan masalah yang dibuat untuk \\
membatasi dan membuat lebih fokus dalam pelaksanaan \\
penelitian adalah mengenai tanggung jawab notaris dalam hal \\
pembuatan akta terkait dengan rapat umum pemegang saham, \\
serta mengkaji aspek perlindungan yang diperoleh seorang \\
notaris terkait pembuatan akta tersebut. Kesimpulan yang \\
diperoleh dari penelitian adalah bahwa menurut Pasal 15 \\
Undang-Undang Nomor 2 Tahun 2014 tentang Jabatan Notaris, \\
Notaris mempunyai kewenangan dalam membuat Akta \\
Pernyataan Keputusan Rapat Umum Pemegang \\
SahamPerseroan Terbatas dan akan menjadi akta otentik jika \\
dibuat kedalam bentuk akta notariil yang disebut Akta \\
Pernyataan Keputusan Rapat Umum Pemegang Saham.
\end{tabular}




\section{Pendahuluan}

Pengertian Notaris menurut Pasal 1 UU Nomor 2 Tahun 2014 adalah pejabat umum yang memiliki wewenang yang sah untuk mengeluarkan surat atau akte resmi serta otentik dan beberapa wewenang terkait sebagaimana dijabarkan pada UU Jabatan Notaris.Dalam Pasal 1 angka 1 Undang-Undang Nomor 2 Tahun 2014 tentang Perubahan Atas Undang-undang nomor 30 Tahun 2004 Jabatan Notaris (UUJN), notaris dapat diartikan sebagai pejabat umum yang mempunyai wewenang untuk membuat surat atau akta resmi dan otentik serta wewenang lain seperti dijelaskan dalam UUJN. ${ }^{1}$

Sebuah akta pada prinsipnya dibuat oleh seorang notaris untuk menciptakan kepastian hukum yang mempunyai fungsi penting terutama terkait dengan setiap urusan terkait hukum, sebab adanya pengesahan dari notaris akan memperkuat bukti bahwa akta tersebut adalah asli dan otentik serta dapat dijadikan alat bukti paling kuat dan paling memenuhi syarat untuk suatu perkara yang berkaitan dengan akta tersebut. Banyak masalah bisnis, misalnya perbankan, masalah pertanahan, sosial, dan lain sebagainya dalam tingkat lokak, daerah ataupun nasional semakin membutuhkan alat pembuktikan yang bagus diantaranya dengan menggunakan akta otentik tersebut.

Dengan sebuah akta yang otentik maka hak dan kewajiban akan menjadi jelas dan kepastian hukum akan lebih bisa dijamin. Adapun akta otentik mempunyai fungsi salah satunya sebagai alat bukti tertulis yang paling berpengaruh dan penuh dan mempunyai peran sangat signifikan yang digunakan untuk menyelesaikan perkara secara efektif dan efisien, cepat dan juga tidak membutuhkan banyak biaya. ${ }^{2}$

Penjelasan tentang jabatan seorang notaris telah dijelaskan secara gamblang didalam Undang-undang Nomor 2 Tahun 2014, khususnya pasal 15 yang terdiri dari :

(1) Ada kewenangan yang dimiliki seorang notaris dalam hal mengeluarkan Akta Otentik yang berisikan tentang perjanjian, ketetapan, ataupun perbuatan yang diatur oleh undang-undang dan telah diberikan mandat resmi oleh pihak yang berkepentingan atas akta otentik tersebut. Hal-hal lain yang juga bisa dipastikan oleh seorang Notaris adalah pembuatan, penyimpanan, salinan serta kutipan dari sebuah akta menurut undang-undang yang berlaku.

(2) Beberapa kewenangan diluar dari yang dijelaskan didalam ayat (1) diantaranya:

a. Untuk memberikan pengesahan terhadap tanda tangan dan juga membuat kepastian dari sebuah surat yang dibuat tidak dihadapan notaris atau pejabat berwenang lainnya (dibawah tangan)

b. surat dibawah tangan yang telah dibuat harus dimasukkan dalam suatu buku khusus; c. mengeluarkan salinan asli dari surat yang dibuat tanpa dihadiri notaris atau disebut surat bawah tangan dan dijelaskan secara detail pada surat tersebut;

d. membuat validasi terhadap fotokopi surat asli;

e. melakukan penyuluhan hukum yang berkaitan dengan akta yang telah dibuat;

\footnotetext{
${ }^{1}$ Abdul Ghofur Anshori, 2009, Lembaga Kenotariatan Indonesia, Perspektif Hukum dan Etika, UII Press, Yogyakarta, hlm.14

2 Ibid.
} 
f. berwenang untuk membuat atau mengeluarkan akta atau surat-surat terkait kepemilikan tanah; atau

g.mengeluarkan surat atau dokumen resmi terkait pelaksanaan lelang

(3) Selain kewenangan sebagaimana dimaksud pada ayat (1) dan ayat (2), Notaris mempunyai kewenangan lain yang diatur dalam peraturan perundang-undangan."

Menurut UU Nomor 40 Tahun 2007, Notaris mempunyai fungsi sebagai pejabat yang sah dan berwenang dalam membuat akta pendirian, peralihan saham dan juga akta perubahan anggaran dasar Perseroan Terbatas. Terkait dengan hal itu maka disini akan dibahas tentang peranan notaris dalam merubah nama Perseroan Terbatas yang artinya juga harus melakukan perubahan pada anggaran dasar Perseroan Terbatas tersebut. Akta yang dibuat untuk melakukan penyesuaian pada anggaran dasar Perseroan Terbatas merupakan hal yang sangat penting, karena akta itu ditempatkan sebagai peraturan yang kuat untuk para pihak dan juga notaris yang menjadi jaminan bahwa anggaran dasar Perseroan Terbatas yang telah mengalami tidak melanggar peraturan dan dan perundang-undangan yang relevan sehingga pihak yang berwenang dari Kementerian Hukum dan HAM mau mengesahkannya. ${ }^{3}$

Perseroan Terbatas (PT) adalah suatu bentuk usaha yang lebih dominan dipilih oleh para pelaku ekonomi, alasannya adalah karena tanggung jawab yang bersifat terbatas juga mudahnya pemilik perusahaan (shareholders) dalam hal memindahkan hak kepemilikan perusahaan (kepada pihak lain) dengan cara menawarkan semua saham yang ia miliki didalam perusahaan, dan keuntungan atau dividen atas saham tersebut. ${ }^{4}$

Dalam Undang-Undang Nomor 40 Tahun 2007 khususnya Pasal 21, dijelaskan bahwa perusahaan yang akan mengubah anggaran dasarnya diwajibkan memperoleh lebih dulu izin dari Menteri, selanjutnya perubahan tersebut harus dimasukkan atau dituangkan kedalam bentuk akta yang menggunakan bahasa Indonesia. Sementara itu, didalam UU tersebut juga, ada beberapa pasal yang memberikan tekanan terhadap jangka waktu untuk membuat permohonan, yaitu tidak melampau waktu yang telah ditetapkan dimana akta tersebut menjadi penentu diberikannya persetujuan menteri atau tidak.

Oleh karena itu, jika pembuatan akta notaris telah melampau waktu yaitu lebih dari tiga puluh hari (30) berdasarkan Undang-undang Nomor 40 Tahun 2007 tentang Perseroan Terbatas (UUPT) sejak dibuatnya akta oleh notaris akan menyebabkan menteri tidak memberikan persetujuannya. Dari uraian tersebut sudah jelas bahwa apabila sebuah permohonan terkait dengan akta terkait anggaran dasar sudah berlalu lebih dari 30 (tiga puluh) hari setelah pembuatan akta maka akan diterima atau disetujui oleh menteri.

Modal Perseroan Terbatas (PT) diperoleh dari berbagai sumber termasuk saham yang dimiliki/dikeluarkan oleh PT, dengan demikian dapat dijelaskan bahwa PT tidak bisa terlepas dari saham. Saham PT yang merupakan hak milik PT ataupun hak milik pihak lain berpengaruh dalam menentukan banyaknya dukungan pada suatu RUPS terhadap masalah yang dibahas. Berdasarkan UU Nomor 40 Tahun 2007 khususnya Pasal 75-91,

\footnotetext{
${ }^{3}$ Ahmad Yani dan Gunawan Wijaya, Perseroan Terbatas, Raja Grafindo Persada, hal.1

${ }^{4}$ Ibid.
} 
dan ketentuan yang diatur dalam Pasal 1 angka 4 UUPT dijelaskan bahwa Rapat Umum Pemegang Saham (RUPS) merupakan elemen dari sebuah perusahaan dengan wewenang khusus yang tidak diperoleh atau diserahkan kepada Direksi atau Dewan Komisaris dengan batasan telah ditetapkan dalam anggaran dasar ataupun peraturan terkait."

Menurut ketentuan itu bisa dirumuskan satu kesimpulan yaitu Rapat Umum Pemegang Saham (RUPS) mempunyai kedudukan yang lebih tinggi daripada direksi ataupun Dewan Komisaris pada sebuah Perseroan Terbatas. Dalam sebuah perusahaan, shareholder tidak mempunyai kedudukan sebagai pemilik kedaulatan paling tinggi tetapi kebanyakan pemegang saham bisa memberikan pengaruh atas kebijakan yang dibuat atau akan dibuat didalam sebuah Perseroan Terbatas. Tetapi pemegang saham akan mempunyai kekuasaan jika pemegang saham hadir pada Rapat Umum Pemegang saham dihadiri yang merepresentasikan kehendak kolektif para pemegang saham.

Namun, kekuasaan dari Rapat Umum Pemegang Saham mempunyai batasan-batasan menurut Undang-undang No.40 tahun 2007 dan atau Anggaran Dasar Perseroan Terbatas.

Ada dua Rapat Umum Pemegang Saham (RUPS) yaitu RUPS tahunan dan RUPS Luar Biasa. RUPS yang dilangsungkan setidaknya dalam periode waktu 6 (enam) bulan disebut sebagai RUPS tahunan, biasanya dilaksanakan setelah tutup tahun buku, atau jika memang memang kondisi mengharuskan dilaksanakannya RUPS kapan saja tanpa dijadwalkan sebelumnya. RUPS yang dilaksanakan oleh sebuah Perseroan Terbatas untuk membuat berbagai kebijakan untuk kepentingan perseroan dan merupakan elemen penting dari sebuah Perseroan Terbatas. RUPS pada pokoknya akan dimasukkan pada sebuah akta otentik didepan seorang notaris atau dituangkan dalam bentuk kedalam akta dibawah tangan dan seteruskan akan diubah menjadi akta otentik.

Sebagai seorang pejabat umum Notaris ada kewenangan yang diberikan terkait pembuatan akta otentik berdasarkan peraturan umum atau menurut permintaan para pihak yang mempunyai kepentingan terhadap akta tersebut. Oleh karena itu, notaris tidak boleh melanggar ketentuan yang diterapkan atasnya sebagai pejabat umum. Berdasarkan konteks ini, notaris mendapatkan kewenangan dan perlindungan hukum terkait dengan dibuatnya akta pernyataan keputusan rapat perseroan yang menjadi bahasan yang menarik untuk diteliti lebih jauh. Adapun fokus masalah didalam penelitian ini sendiri adalah tentang kewenangan notaris didalam pembuatan akta pernyataan keputusan rapat umum pemegang saham perseroan terbatas. Dari uraian diatas maka, maka penulis membuat penelitian dengan judul "Kewenangan Notaris Dalam Pembuatan Akta Pernyataan Keputusan Rapat Umum Pemegang Saham Perseroan Terbatas di Kabupaten Badung".

\section{Metode Penelitian}

Ada dua jenis penelitian hukum, yakni penelitian hukum normatif dan juga penelitian hukum empiris. ${ }^{5}$ Penulis menggunakan metode penelitian hukum empiris dalam

\footnotetext{
${ }^{5}$ Mukti Fajar ND dan Yulianto Achmad, 2010. Dualisme Penelitian Hukum Normatif \& Empiris, Pustaka Pelajar, Yogyakarta, hal. 153
} 
mengerjakan penelitian ini. Pengertian dari penelitian hukum empiris yaitu penelitian yang dilakukan untuk menganalisis dan mengkaji hukum secara riil dengan kata lain merupakan penelitian yang melihat bagaimana hukum digunakan dengan sebenarnya didalam masyarakat. ${ }^{6}$ Peneliti menggunakan metode penelitian ini karena objek dari penelitian diperoleh langsung didalam pelaksanaan praktek kenotariatan, yang berkaitan dengan kewenangan notaris dalam pembuatan akta pernyataan keputusan rapat umum pemegang saham perseroan terbatas.

1. Data primer, adalah data dari narasumber langsung, penelitian dilapangan dilakukan dengan menggunakan teknik pengumpulan data dengan wawancara.

2. Data sekunder, adalah semua data pendukung data primer yang sudah ada. Datadata sekunder yang digunakan diantaranya:

a. Peraturan dan perundang-undangan relevan dengan masalah notaris dan juga perseroan terbatas atau bahan hukum lain yang mempunyai kekuatan mengikat atau disebut bahan hukum primer yaitu sebagai berikut:

I. Kitab Undang-Undang Hukum Pidana

II. Undang-Undang Nomor 40 Tahun 2007 tentang Perseroan Terbatas

III. Undang-Undang Nomor 2 Tahun 2014 tentang Jabatan Notaris

b. Buku, penelitian terdahulu, review dan jurnal serta sumber bacaan lainnya yang merupakan pendukung untuk melakukan analisis bahan hukum primer disebut bahan hukum sekunder.

Data primer digunakan oleh peneliti dikumpulkan dengan teknik penelitian studi dokumen yang merupakan teknik pendahuluan didalam melakukan penelitian hukum. Teknik pengumpulan data yang kedua adalah melakukan wawancara dengan terlebih dahulu membuat guide interview atau petunjuk wawancara dengan mempersiapkan beberapa pertanyaan yang akan diajukan kepada informan, yang tujuannya untuk mendapatkan jawaban yang relevan terhadap masalah penelitian.

Analisis kualititif digunakan untuk melakukan analisis terhadap data penelitian. Dengan data yang sudah dikumpulkan melalui hasil wawancara di Kantor Notaris / PPAT Mahayani Widiana Kedel secara lengkap dan teratur, maka data kemudian diproses melalui beberapa langkah umum seperti berikut:

a. Data yang didapatkan dari lapangan kemudian akan ditulis atau diketik menjadi deskripsi atau uraian dalam bentuk laporan yang lengkap. Isi laporan adalah rangkuman hal-hal pokok dan terpenting yang pada akhirnya akan menghasilkan tema serta pola dari data tersebut.

b. Data yang telah dikumpulkan akan dirangkum dan menjadi kesimpulan seperti dijelaskan pada poin a, dilanjutkan dengan pencarian pola, relevansi, persamaan serta hal-hal yang terjadi selanjutnya dibuat kesimpulan.

\section{Hasil dan Pembahasan}

\subsection{Kewenangan Notaris Dalam Pembuatan Akta Pernyataan Keputusan Rapat Umum Pemegang Saham Perseroan Terbatas.}

${ }^{6}$ Lexy. J. Moleong, 2006. Metodologi Penelitian Kualitatif, PT. Remaja Rosdakarya, Bandung, Hal. 26. 
Perjanjian yang dibuat dalam bentuk tulisan atau tertulis bisa diartikan sebagai satu kepentingan dari pihak yang membuat perjanjian untuk menjadikannya sebagai alat bukti. Perjanjian ini nantinya akan menjadi akta otentik yang mempunyai kekuatan lebih daripada akta yang dibuat dibawah tangan, serta bisa dijadikan alat bukti yang sempurna didalam perkara hukum. Tetapi pada kenyataannya, masih terdapat perjanjian dibawah tangan yang selanjutnya harus dibawah kehadapan notaris untuk dikuatkan menjadi akta otentik. ${ }^{7}$

Dasar dari penyelenggaraan RUPS adalah pasal 78, pasal 79, pasal 80 dan juga pasal 81 dari Undang-Undang Perseroan Terbatas. Ditinjau dari aspek waktu pelaksanaan Rapat Umum Pemegang Saham dibedakan menjadi dua yaitu, Rapat Umum Pemegang Saham Tahunan dan Rapat Umum Pemegang Saham luar biasa, menurut Pasal 78 Undang-undang Perseroan Terbatas. Rapat Umum Pemegang Saham Tahunan wajib dilaksanakan setiap tahun, dimana ketentuan penyelenggaraannya adalah dilaksanakan dalam periode waktu sekurang-kurangnya 6 (enam) setelah penutupan tahun buku. Sementara itu, Rapat Umum Pemegang Saham Luar Biasa akan diadakan ketika diperlukan tanpa ada ketentuan waktu spesifik, sehingga bisa dilakukan jika para ada kondisi atau kebutuhan terkait kepentingan Perseroan Terbatas. Ketika Rapat Umum Pemegang Saham dilaksanakan, maka harus dibuat risalah rapat, jika tidak ada maka Rapat Umum Pemegang Saham tersebut dianggap tidak pernah dilaksanakan. ${ }^{8}$

Setiap hal atau topik dan putusan apapun yang dimasukkan kedalam rapat harus dibuat kedalam catatan atau notulen. Namun pencatatan itu tidak wajib dibuat dihadapan seorang notaris. Pencatatan itu bisa dilakukan dihadapan notaris yang disebut akta dibawah tangan namun bisa juga dibuat menjadi akta otentik dengan notaris. Didalam prakteknya, pembuatan catatan atau risalah tanpa notaris disebut sebagai "notulen", sementara jika dicatat oleh seorang notaris akan disebut sebagai Berita Acara Rapat Umum Pemegang Saham. ${ }^{9}$

Jika berdasarkan pada 90 ayat (1), risalah itu akan ditanda-tangani oleh ketua rapat jika dibuat dibawah tangan. Sebaliknya jika dibuat oleh notaris, maka risalah itu akan dibuat dalam bentuk realisasi akta, atau disebut sebagai berita acara. Karena ini relaas akta maka secara yuridis sebenarnya cukup ditandatangani oleh notaris dan dua orang saksi. Akta Otentik yang dihasilkan ini merupakan salah satu bentuk kompeten dari fungsi yuridis seorang notaris. Akta Otentik, berdasarkan Pasal 1870 KUHPerdata memiliki dasar yang kuat sebagai alat bukti sempurna berkaitan dengan isi akta dan mengikat para pihak yang tercantum didalam akta termasuk orang-orang yang mendapatkan hak berdasarkan akta tersebut. ${ }^{10}$ Pasal 21 ayat (4) menyatakan bahwa anggaran dasar yang telah diubah harus dibuat dalam bentuk akta notaris dan dibuat dengan menggunakan bahasa Indonesia, hal tersebut berarti bahwa bukan berarti hasil keputusan RUPS tidak boleh dibuat secara notulen di bawah tangan, hal tersebut diperbolehkan namun setelah itu direksi dan komisaris akan diberi kuasa oleh RUPS

\footnotetext{
${ }^{7}$ Azizah, 2016, Hukum Perseroan Terbatas, Setara Press, Malang, hal.17.

${ }^{8}$ M. Yahya Harahap, 2015, Hukum Perseroan Terbatas, sinar grafika, Jakarta, hal. 340

${ }^{9}$ Rudi Prasetya, 2011, Perseroan Terbatas teori dan Praktek, Sinar Grafika, Jakarta, hal.60

${ }^{10}$ M. Yahya Harahap, loc.cit ,hal. 341
} 
untuk menghadap notaris dan selanjutnya notaris membuat akta pernyataan keputusan rapat (PKR). ${ }^{11}$

Berdasarkan wawancara yang dilakukan, Notaris/PPAT Mahayani Widiana Kedel menyatakan bahwa, Akta Pernyataan Keputusan Rapat Umum Pemegang Saham Perseroan Terbatas, adalah akta notaris dengan fungsi berkaitan urusan perseroan. Menurut UUPT hasil dari Rapat Umum Pemegang Saham bisa dimasukkan kedalam akta autentik ataupun akta di bawah tangan. Namun jika ditinjau kembai bahwa tidak semua hasil RUPS dituangkan kedalam akta autentik maka para pemilik kepentingan dari suatu perseroan kemungkinan menyelenggarakan RUPS tidak dengan keberadaan seorang Notaris. Oleh karena itu untuk membuat hasil Rapat Umum Pemegang Saham itu menjadi lebih kuat maka perusahaan akan memberikan kuasa kepada salah seorang direktur untuk menjadikan putusan Rapat Umum Pemegang Saham tersebut kedalam sebuah akta otentik yang selanjutnya akan akan disebut sebagai Akta Pernyataan Keputusan Rapat Umum Pemegang Saham Perseroan Terbatas. Kemudian Notaris/PPAT Mahayani Widiana Kedel juga mengatakan bahwa beberapa syarat yang harus dipatuhi oleh dalam membuat Akta Pernyataan Keputusan Rapat Umum Pemegang Saham Perseroan Terbatas yaitu sebagai berikut:

1. Perusahaan harus menyerahkan dokumen asli keputusan RUPS;

2. Direksi dengan wewenang yang dipegangnya menurut keputusan RUPS akan menghadap notaris dan memberikan tanda tangan diatas akta serta memberikan:

Salinan Akta Pendirian Perseroan

I. Terbatas beserta perubahannya;

II. Surat Keputusan Menteri Hukum dan HAM RI tentang pemberian status badan hukum suatu perseroan terbatas;

III. Foto Copy KTP Direksi dan Komisaris Perseroan Terbatas tersebut;

IV. Nomor Pokok wajib Pajak (NPWP) Perseroan;

V. Surat Keterangan Domisili Perseroan;

VI. Surat-surat lainnya seperti: Surat Izin Usaha Perdagangan (SIUP), Tanda Daftar Perusahaan (TDP).

Apabila dikaitkan dengan teori kewenangan maka dalam hal ini maka notaris memiliki kekuasaan formal, yaitu kuasa yang didapatkan menurut undang-undang, dalam hal ini termasuk juga dalam menuangkan hasil dari RUPS menjadi akta yang disebut sebagai akta pernyataan keputusan rapat. Apabila dikaitkan denga teori kepastian hukum maka disini notaris dissamping membuat akta notaris juga mempunyai tanggung jawab untuk memberikan informasi terkait ketentuan hukum dalam pembuatan akta pernyataan keputusan rapat. Sehingga dalam hal ini notaris memberikan jaminan kepastian hukum bahwa apa yang dilakukan para pihak telah sesuai dengan hukum yang berlaku.

\subsection{Perlindungan Hukum Bagi Notaris Dalam Pembuatan Akta Pernyataan Keputusan Rapat Umum Pemegang Saham Perseroan Terbatas}

Notaris harus bertanggung jawab sepenuhya terhadap semua dokumen resmi termasuk akta dengan tanda atau telah disahkannya sebagai realisasi kepentingan para pihak yang membuat akta tersebut. Tanggung jawab tersebut sangat relevan dengan

11 Ibid. hal.62 
fungsi dan wewenang serta moralitas notaris baik secara pribadi ataupun ditinjau dari kedudukannya sebagai pejabat umum. Namun sebuah akta bisa batal demi hukum jika terjadi kesalahan ketika membuat akta, sehingga jika ini dapat dibuktikan maka akta tersebut bisa dianggap tidak lagi otentik. ${ }^{12}$

Berdasarkan pendapat dari Sudikno Mertokusumo pengertian hukum yaitu semua peraturan dan ketentuan yang berlaku didalam satu kehidupan atau semua prilaku yang ditunjukkan dalam kehidupan masyarakat yang pelaksanaannya bersifat wajib atau dibuat sanksi atas pelanggarnya. ${ }^{13}$ Oleh karena itu, jika dihubungkan pada aspek perlindungan hukum maka bisa dimaknai sebagai pemberi jaminan kepastian hukum, yaitu dimana seseorang akan memperoleh hak dan juga kewajiban serta perlindungan atas kepentingan dengan perasaan aman menurut aturan atau kaidah yang telah ditentukan dalam kehidupan sosial.

Seseorang akan diukur dan dimintai tanggung jawab atas perbuatan secara praktis jika ia melakukan perbuatan yang melanggar hukum dan jika ditinjau berdasarkan KUHPerdata yang disebut sebagai perbuatan melawan hukum (onrechtmatige daad). ${ }^{14}$ KUHPerdata Buku III Bab III telah menjelaskan tentang Onrechtmatige daad atau perbuatan melawan hukum terkait perikatan-perikatan dibuat berdasarkan undangundang, Pasal 1365 sampai dengan Pasal 1380. Bunyi dari Pasal 1365 KUHPerdata adalah "Tiap perbuatan hukum yang membawa kerugian kepada seorang lain mewajibkan orang yang karena salahnya menerbitkan kerugian itu, mengganti kerugian tersebut." Berdasarkan ketentuan di atas, dapat dikemukakan unsurunsurnya yaitu ${ }^{15}$ (1) perbuatan; (2) melawan hukum; (3) pihak pelaku; (4) kerugian terhadap korban; (5) Kausalitas perbuatan dan kerugian.

Onrechtmatige daad yang diterjemahkan kedalam bahasa Belanda sebagai perbuatan melanggar hukum sebagaimana dijelaskan oleh Wirjono Prodjodikoro dengan istilah yang dalam bahasa Belanda diartikan secara terbatas seperti yang digunakan pada Pasal 1365 KUHPerdata serta yang terkait pada penafsiran dari pasal tersebut. Salah satu hukum di Indonesia yang paling sering menggunakan istilah pelanggaran hukum secara khusus adalah pada Hukum Adat. ${ }^{16}$ Kewenangan serta kekuasaan umum diberikan juga kepada Notaris yang mempunyai kedudukan sebagai pejabat umum, pada hal-hal yang terkait dengan public openbaar gezag. ${ }^{17}$ Sebagai pejabat umum, Notaris yang pengangkatannya dilakukan oleh negara mempunyai hak dan kewajiban untuk melaksanakan tugas-tugas negara terkait dengan bidang hukum perdata. Tugas negara tersebut sama seperti para hakim, jaksa, angota dewan dan lain-lain, tetapi perbedaannya adalah negara tidak memberikan gaji kepada Notaris. Namun, notaris

12 Tan Thong Kie, 2000, Studi Notariat (serba-serbi Praktek Notaris), PT. Ichtiar Baru Van Hoeve, Jakarta, h. 149

${ }^{13}$ Sudikno Mertokusumo. 1986. Mengenal Hukum: suatu pengantar, Yogyakarta. Liberty, hal. 1

${ }^{14}$ Subekti dan Tjitrosudibio, 1961, Kitab Undang-Undang Hukum Perdata , Cet. 28, Jakarta, PT Pradnya Paramita, hal. 346.

${ }^{15}$ R. Wirjono Prodjodikoro, 1983, Asas-asas Hukum Perdata , Cetakan 9, Sumur, Bandung, , hal. 80

16 Wirjono Prodjodikoro, 1993, Perbuatan Melanggar Hukum, Bandung, Sumur Bandung, hal. 7

17 R. Sugondo Notodisoerjo, 1993 Hukum Notariat di Indonesia suatu penjelasan, Raja Grafindo Persada, Jakarta, hal.44 
akan mendapatkan honor menurut pasal 36 UUJN yang telah mengatur secara lengkap terkait hal ini.

Dalam memberikan pelayanan (public service) notaris mempunyai wewenang menurut undang-undang terkait dalam hal pembuatan akta haruslah dijamin melalui adanya pengawasan, sehingga dapat terhindar dari penyalahgunaan wewenang ataupun perbuatan yang melawan hukum. Tujuan inti dari adanya pengawasan tersebut adalah tidak lain dan tidak bukan supaya semua notaris dapat memperoleh semua hak dan menjalankan kewajiban sesuai dengan kewenangannya berdasarkan hukum yang telah ditentukan dan berlaku serta prinsip-prinsip moral, etis dan profesi demi menjamin adanya perlindungan dan juga kepastian hukum bagi masyarakat.

Selain itu, cara lainnya terkait dengan pengawasan notaris terkait dengan perlindungan hukum bagi notaris ketika melaksanakan tugasnya dimana seorang notaris dapat melakukan berbagai jenis kesalahan baik bersifat pribadi ataupun profesionalitas ketika menjalankan tugasnya, maka UUJN menggolongkan jabatan notaris dalam pejabat umum maka seorang notaris memerlukan perlindungan hukum dengan dasar profesi, bukan dengan dasar pribadi. ${ }^{18}$ Diperlukan upaya hukum nonyudisial untuk mendapatkan perlindungan hukum yang efektif bagi notaris salah satunya dengan cara melalui jalur peradilan atau yudisal. Agar tidak terjadi pelanggaran oleh notaris maka ada upaya hukum non yudisial berupa teguran, peringatan ataupun somasi. ${ }^{19}$ Secara normatis, perlindungan hukum bagi notaris menurut aturan dan UU adalah:

a. Berdasarkan isi dari Pasal 67 UUJN, dibentuknya Majelis Pengawas oleh Menteri mencakup 3 (tiga) pihak, yaitu 3 (tiga) orang berasal dari pihak pemerintah, 3 (tiga) orang berasal dari organisasi Notaris, 3 (tiga) orang berasal dari akademisi. Pengawasan tersebut meliputi pelaksanaan jabatan Notaris;

b. Isi dari Pasal 50 KUHP tentang perlindungan hukum bagi Notaris yang menyatakan orang yang melakukan kegiatan untuk menyelenggarakan peraturan dan perundang undangan, tidak dapat dipidana.

c. Hak Ingkar Notaris sebagaimana diatur dalam:(1)Pasal 170 KUHAP;(2)Pasal 1909 angka 3 KUHPerdata;(3)Pasal 4 ayat (2) UUJN dan (4)Pasal 16 ayat 1 huruf (e) UUJN.

d. Nota Kesepahaman antara Kepolisian Negara Republik Indonesia dengan Ikatan Notaris Indonesia Nomor 01/MOU/PP-INI/V/2006 tentang Pembinaan dan Peningkatan Profesionalisme di Bidang Penegakan Hukum;

e. Surat Keputusan Majelis Pengawas Pusat Nomor C-MPPN.03.10-15 tentang Pemberian atau Penolakan Persetujuan Pemanggilan Notaris oleh penyidik, penuntut umum dan hakim.

Apabila ditemukan pelanggaran yang dilakukan oleh notaris terkait akta pernyataan keputusan rapat umum pemegang saham perseroan maka ia tidak dapat digugat atas dasar wanprestasi, walaupun ada kesalahan yang dibuat oleh Notaris sebagai pada dasarnya pembuatan partij akta tidak termasuk perjanjian yang dilakukan antara

18 Harjono, 2008, Konstitusi Sebagai Rumah Bangsa, sekretariat jenderal dan kepaniteraan mahkamah konstitusi, Jakarta, hal.385

${ }^{19} \mathrm{Ibid}$. 
pihak-pihak berkepentingan dan notaris, jadi terhadap kebenaran materiil dari partij akta apabila bertentangan dengan yang sebenarnya terjadi notaris tidak bertanggung jawab. ${ }^{20}$ Apabila dikaitkan dengan teori perlindungan hukum, maka pentingnya perlindungan hukum bagi notaris adalah untuk menghindari munculnya perselisihan atau yang membuat pemerintah menerapkan sikap hati-hati untuk membuat suatu keputusan.

\section{Kesimpulan}

Berdasarkan Pasal 15 UUJN telah dinyatakan secara jelas tentang kewenangan notaris terkait pembuatan akta pernyataan keputusan rapat yang para prinsipnya adalah memberi wewenang kepada notaris untuk membuat Akta Otentik terkait dengan perbuatan, perjanjian dan juga penetapan yang ditetapkan menurut peraturan perundang-undangan atau berdasarkan keinginan pihak yang mempunyai kepentingan dalam hal pembuatan Akta Otentik tersebut. Notaris juga mempunyai wewenang untuk membuat jaminan atas tanggal pembuatan Akta, penyimpanan Akta, pemberian grosse, membuat salinan dan juga kutipan-kutipan terkait dengan Akta. Selanjutnya pada pada pasal 21 UU Perseroan Terbatas pada pokoknya menjelaskan bahwa anggaran dasar perseroan terbatas yang telah diubah harus dimasukkan dalam akta notaris dan dibuat dalam bahasa Indonesia. Oleh karena itu berdasarkan uraian diatas dapat dijelaskan bahwa kewenangan notaris mempunyai batasan untuk mencantumkan hasil RUPS didalam akta pernyataan keputusan RUPS Perseroan Terbatas. Dengan demikian hasil dari keputusan RUPS akan menjadi akta otentik walaupun awalnya adalah akta yang dibuat dibawah tangan. Wewenang lain dari notaris adalah memberikan jaminan kepastian hukum atau legal certainty bagi pihak yang berkepentingan dalam akta yang telah dibuat. Kepastian hukum yang dimaksudkan adalah untuk memberitahukan kepada para pihak yang berkepentingan tentang apa yang boleh dibebankan atau tidak boleh dibebankan menurut ketentuan hukum yang diterapkan dan berlaku.

Berkaitan dengan perlindungan Hukum yang berlaku terhadap Jabatan Notaris Dalam pembuatan akta keputusan rapat umum pemegang saham yang telah dibuat berdasarkan UUJN notaris bukanlah pihak dalam akta yang mempunyai kewajiban nama Notaris tidak perlu dicantumkan didalam akta tidak serta merta membuat notaris dilibatkan atau ditempatkan sebagai tergugat/turut tergugat attau terlapor ketika para penghadap dan pihak lain bukan penghadap mempunyai masalah terkait dengan akta yang telah dibuat.

\section{Daftar Pustaka}

$\underline{\text { Buku }}$

Anshori, Abdul Ghofur (2009). Lembaga Kenotariatan Indonesia, Perspektif Hukum dan Etika. Yogyakarta: UII-Press

Azizah, 2016, Hukum Perseroan Terbatas, Setara Press, Malang. Fajar Nd, Mukti. dan Yulianto Achmad.(2010). Dualisme Penelitian Hukum Normatif \& Empiris. Yogyakarta: Pustaka Pelajar Harahap, M. Yahya.(2009).Hukum Perseroan Terbatas. Jakarta: Sinar Grafika.

${ }^{20}$ M.A. Moegni Djojodirdjo, 1979, Perbuatan Melawan Hukum, Pradnya Paramita, Jakarta, hal. 13 
Kie, Tan Thong. (2015). Studi Notariat: Beberapa Mata Pelajaran dan Serba-Serbi Praktek Notaris. Cetakan 3. Jakarta: Ichtiar Baru Van Hoeve

Mertokusumo, Sudikno. (1998) Hukum Acara Perdata Indonesia. Yogyakarta: Liberty

Moleong, Lexy J., (2013). Metodologi Penelitian Kualitatif, Edisi Revisi. Bandung: PT. Remaja Rosdakarya

Notodisoerjo, R. Soegondo. (1982). Hukum Notariat di Indonesia, Rajawali, Jakarta.

Prasetya, Rudhi. (2004). Kedudukan Mandiri Perseroan Terbatas. Bandung: Citra Aditya Bakti.

Prodjodikoro, Wirjono. (1989). Azas-azas Hukum Perjanjian. Bandung, Sumur Bandung.

Subekti, R., (1996) Pokok-pokok Hukum Perdata. Jakarta: Intermasa.

Yani, Ahmad dan Wijaya Gunawan. (1999). Perseroan Terbatas. Jakarta: Raja Grafindo Persada.

Peraturan Perundang-Undangan:

Kitab Undang-Undang Hukum Perdata.

Undang-Undang Nomor 40 Tahun 2007 tentang Perseroan Terbatas.

Undang-Undang Nomor 2 Tahun 2014 tentang Perubahan Atas UndangUndang Nomor 30 Tahun 2004 tentang Jabatan Notaris. 